\title{
Knowledge of improved dairy husbandry practices of farmers of Kauroli, district of eastern Rajasthan
}

\author{
Bacchu Singh' Kamla Mahajani \& KC Meena
}

Journal of Agriculture and Ecology

Volume-9 (Jube, 2020)

Journal of

ISSN: 2456-9410

Volume: 9

Journal of Agriculture and Ecology (2020) 9: 48-54 http://doi.org/10.53911/JAE.2020.9105

कुषि एवं शुष्क पारिस्थितिकी अनुसंधान साझाइटी Society for Ägriculture and Arid Ecology Research Bikaner (Rajasthan) INDIA-334006 Website: www.sager.org. in 


\section{Knowledge of improved dairy husbandry practices of farmers of Kauroli, district of eastern Rajasthan}

Bacchu Singh ${ }^{1}{ }^{\prime}$ Kamla Mahajani ${ }^{2} \&$ KC Meena ${ }^{3}$

${ }^{1 \& 2}$ Krishi Vigyan Kendra, Hindaun (Karauli)

${ }^{3}$ Krishi Vigyan Kendra, Swaimadhopur

7 Corresponding author: B Singh, bs meena38@yahoo.com

\section{Article Info}

Article history

Received: 20 May 2020

Accepted: 10 June 2020

Available online: 30 June 2020
Key Words: Knowledge

level; animal, feed practices, breeding, disease control.

\section{Abstract}

This study was carried out in the randomly selected 20 villages of Hindaun and Todabhim blocks of Karauli District of eastern Rajasthan. The results of the present study revealed that the majority of the farmers $(73 \%)$ had partial level of knowledge about overall dairy practices, while 16 per cent farmers had full level of knowledge about overall dairy practices and 11 per cent, who had no level of knowledge about overall dairy practices. The majority of the respondents had partial knowledge about feeding elements, feeding of concentrates and roughage mixture, time of feeding concentrate, feed requirements for maintenance of animals, feed requirements for production purpose, green fodder requirements, extra essential minerals requirement to animals with concentrate and roughage and quantity of minerals required per day per animal, animal breeding programme, improved breeds of bull, artificial insemination, time of next insemination after parturition of animals, pregnancy diagnosis and sources of artificial insemination carried out by artificial insemination centre, vaccination programme to control the diseases vaccination schedule, control of foot and mouth diseases control of hemorrhagic septicemia diseases, control of black quarter diseases and control of anthrax diseases. It was also found that majority of the respondents had partial knowledge about keeping the records of animals, method of determining the age of animals and proper method of milking. It can be concluded that majority of the respondent had partial knowledge about feed practices, breeding practices, disease control practices and general management practices.

Copyright (C2020 Singh et al., This is an open access article published under the terms of the Creative Commons Attribution License, which permits unrestricted use, distribution, and reproduction in any medium, provided the original work is properly cited.

Preferred citation: Singh B, Mahajani K \& Meena KC. 2020. Knowledge of improved dairy husbandry practices of farmers of Kauroli, district of eastern Rajasthan. Journal of Agriculture and Ecology, 9: 48-54; http://doi.org/10.53911/JAE.2020.9105.

\section{Introduction}

The role of livestock is increasing in Indian economy. It contributed to nearly 16 per cent of total income from agriculture in 1970-71, which increased to over 25 per cent in 2002-03 (Meena \& Singh 2013). This will continue to be so in the coming period due to various economic factors like increase in the population, urbanization and per capita income growth. The Animal Husbandry and 
livestock sectors are critical for the rural economy, especially the small and marginal farmers. They not only contribute to their income but also their best insurance against any natural calamity. The role of livestock is much pronounced in the arid and semi arid regions like Rajasthan, which is prone to drought and resultant crop failure. At the time of crop failure, livestock sector acts as a cushion on which the farmers can fall upon.

India is the world's single largest milk producing country with a share of about 14 per cent in world milk production. Milk has achieved a unique status in terms of its output value and contribution to the national economy, with output value exceeding Rs. 100000 crores and has made rapid strides both in terms of number of milk producers and quantity of milk produced. The White Revolution has demonstrated that the power of scale can be effectively acquired by milk producers if they work in cooperative manner with the use of improved dairy practices. As a result, the milk production reached the level of about 176 millions tones at the end of recent data be depicted compared to 17 million tones in 1950-51. The livestock sector alone contributes nearly $27.4 \%$ of value of output at current prices of total value of output in Agriculture, Fishing \& Forestry sector. The overall contribution of Livestock Sector in total GDP is nearly $4.10 \%$ at current prices during 2017-18 (BAHS 2019). The unique characteristic of Indian dairy industry is that the bulk of milk production in our country is handled by small milk producers who are illiterate and unaware of economic aspects of milk production. Therefore, there is a need for poverty alleviation to be strengthened through dairying as enterprise.

Most of the rural dairy farmers, who keep dairy animals, do not follow scientific and modern animal husbandry practices which have been evolved through considerable quantum of research work carried out by the scientist resulted from decades of hard work. There is an urgent need to sensitize the dairy farmers towards the modern technologies and scientific interventions in dairy production, in order to enhance milk yield and milk quality from dairy animals. Keeping the above problems in view, the present study was taken up with the specific objectives to study the knowledge regarding recommendations pertaining to improved animal husbandry practices of the dairy farmers

\section{Materials and Methods}

The investigations were carried out in the randomly selected 20 villages of Hindaun and Nadauti blocks of Karauli District of eastern Rajasthan because it is the potential district for dairy production. The dairy farmers having dairying as their major or subsidiary occupation were randomly selected from these villages. For this purpose, a comprehensive list of dairy farmers was prepared with the help of secretaries of milk co-operative societies, artificial insemination worker, sarpanch and village extension worker. From this list, 05 respondents were randomly selected from each village. Thus the sample size of randomly selected respondents was comprised of 100 . The data were collected through the personal interview to get most authentic first hand information with the view of the objectives of the study. For data 
analysis, average, frequencies and percentages were used.

\section{Result and Discussion}

The foremost objective of dairy enterprise, like other enterprise, is to achieve maximum productivity and profitability. In this regard a vast networking of infrastructure for the development and dissemination of relevant dairy husbandry technologies/practices were designed since the very inception of our planned economic change. It is the hard fact that effective practices management and development of dairy owner specifically their abilities, knowledge and skill are of paramount importance for the mobilization and development of dairy farming. Dairy practices generally involve the integrated application of new technology about feeding, breeding, disease control and general management in a manner suitable for particular situation.

Knowledge Level about feed practices: Food substances are essential for the preservation of the life. The nutritive value of food is required for maintenance, growth and production purpose. Scientists have come to the help of farmers by providing certain guidelines in selecting properly balanced rations for meeting the nutrient requirement of herd. For health point of view and to get the higher milk production, one should understand the process of feeding. In present study efforts have been made to measure the level of knowledge possessed by sample respondents regarding feeding practices of herd. Table 1 revealed the level of knowledge about feed practices measured in terms of variation from improved practices in different aspect by the respondents. Regarding level of knowledge of feeding elements, the findings showed that the majority of $(72 \%)$ farmers had partial knowledge followed by (15\%) who had no knowledge and (13\%) who had full knowledge respectively. About feeding of concentrate and roughage mixture, the majority of $(56 \%)$ farmers had partial knowledge followed by $(27 \%)$ had no knowledge and (17\%) who had full knowledge, respectively. Regarding time of feeding concentrate the majority of $(61 \%)$ farmers had partial knowledge followed by (25\%) had no knowledge and (15\%) had full knowledge respectively. Regarding feed requirement for maintenance of animals the majority of $(63 \%)$ farmers had partial knowledge followed by (32\%) had full knowledge and (6\%) had no knowledge, respectively. Regarding feed requirements for production purpose the majority of $(66 \%)$ farmers had partial knowledge followed by (29\%) had full knowledge and (5\%) had no knowledge, respectively. Regarding use of green fodder (roughage) requirement the majority of $(59 \%)$ farmers had partial knowledge followed by (25\%) had full knowledge and (16\%) had no knowledge, respectively. Regarding extra essential minerals requirement for animals with concentrate and roughage the majority of (54\%) farmers had partial knowledge followed by $(39 \%)$ had full knowledge and $(7 \%)$ had no knowledge, respectively. Regarding quantity of minerals required per day per animal, the finding showed that majority of $(55 \%)$ farmers had partial knowledge followed by (34\%) had full knowledge and (11\%) had no knowledge, respectively. It was found that majority of the 
respondents had partial knowledge about feeding elements, feeding of concentrates and roughage mixture time of feeding concentrate, feed requirements for maintenance of animals, feed requirements for production purpose, green fodder (roughage) requirements, extra essential minerals requirement to animals with concentrate and roughage and quantity of minerals required per day per animal. These findings are in line with findings of Meena et al. (2009).

Knowledge level about breeding practices: Efficient reproduction is an important factor affecting profit from a live- stock enterprise which is the most essential goal of entrepreneur. In another side, efficiency about breeding practices mainly depends on the understanding (Knowledge) of the basic facts and technologies and the application (adoption) of these practices by the respondent. In this line, efforts have been made to measure the level of knowledge possessed by sample respondents regarding breeding practices of the herd. The table 1 depicts that the level of knowledge of animal breeding programme the majority $(62 \%)$ of farmers had partial knowledge $(28 \%)$ followed by had full knowledge (10\%) and who had no knowledge, respectively. About the level of knowledge of improved breeds of bull the majority $(62 \%)$ farmers had partial knowledge followed by $(25 \%)$ had no knowledge and
(13\%) who had full knowledge, respectively. Regarding artificial insemination the majority of $(59 \%)$ farmers had partial knowledge followed by (24\%) had no knowledge and $(17 \%)$ had full knowledge, respectively. Regarding the level of knowledge of time of next insemination after parturition of animals the study showed that the majority of $(54 \%)$ farmers were found to have partial knowledge followed by $(26 \%)$ had no knowledge and $(20 \%)$ who had full knowledge, respectively. Regarding pregnancy diagnosis the study showed that the majority of $(50 \%)$ farmers had partial knowledge followed by (39\%) full knowledge and (11\%) that had no knowledge, respectively. Regarding the knowledge of source of artificial insemination carried out by artificial insemination center the majority of $(55 \%)$ farmers were found to have partial knowledge followed by $(29 \%)$ had no knowledge $(16 \%)$ and who had full knowledge, respectively. It was found that majority of the respondents had partial knowledge about animal breeding programme, improved breeds of bull, artificial insemination, time of next insemination after parturition of animals, pregnancy diagnosis and sources of artificial insemination carried out by artificial insemination centre. These findings are in line with findings of Meena and Chauhan (1999) and Aulakh et al. (2011).

Table 1. Respondent's level of knowledge about improved dairy practices

\begin{tabular}{llccc}
\hline S. No. & Dairy practices & \multicolumn{3}{c}{ No. of respondents (N=100) } \\
& & \multicolumn{2}{c}{ (Level of knowledge) In \% } \\
& & FK & PK & NK \\
\hline (a). & Knowledge level of feed practices & & & \\
1. & Feeding elements & 15 & 72 & 13 \\
2. & Feeding of concentrates and roughage mixture & 17 & 56 & 27
\end{tabular}


3. Time of feeding concentrate

4. Feed requirements for maintenance of animals

$\begin{array}{lll}15 & 61 & 25\end{array}$

5. Feed requirements for production purpose

32

63

06

6. Green fodder (roughage)requirements

29

66

05

7. Extra essential minerals requirement to animals with

25

59

16 concentrate and roughage

8. Quantity of minerals required per day per animal

39

54

07

(b). Knowledge level of breeding practices

1. Animal breeding programme 28

2. Improved breeds of bull 13

3. Artificial insemination 17

34

55

11

$28 \quad 62 \quad 10$

$\begin{array}{lll}13 & 62 & 25\end{array}$

4. Time of next insemination after parturition of animals

$17 \quad 59$

24

$20 \quad 54 \quad 26$

5. Pregnancy diagnosis

$39 \quad 50$

26

6. Sources of artificial insemination carried out by

16

55

11

artificial insemination centre.

(c). Knowledge level of disease control practices

1. Vaccination programme to control the diseases.

$\begin{array}{lll}18 & 55 & 27 \\ 20 & 57 & 23 \\ 41 & 52 & 07 \\ 27 & 59 & 14 \\ 28 & 56 & 16 \\ 16 & 61 & 23\end{array}$

2. Vaccination schedule

3. Control of Foot and Mouth diseases. 07

4. Control of Hemorrhagic Septicemia diseases.

5. Control of Black quarter diseases.

6. Control of Anthrax diseases.

23

(d). Knowledge level of general management

1. Keeping the records of animals. $\quad 14 \quad 66 \quad 20$

2. Method of determining the age of animals. $\quad 22 \quad 54 \quad 26$

3. Proper method of milking.

28

56

16

Note- FK= Full knowledge, PK- Partial Knowledge, NK= No knowledge

Knowledge Level about disease control practices: Diseases mostly cause loss of production and frequently a loss in general health of animal which simultaneously affects the loss of money and value of the enterprise. Knowledge about diseases and their control measure is definitely helpful to -farmers in respect of profitability of enterprise. The data depicted in table 1 shows the level of knowledge possessed by respondents regarding main diseases of animal and their control measures. It has been observed from the study that the majority of the farmers (55\%) had partial knowledge about vaccination programme to control the disease followed by $(27 \%)$ respondents had no knowledge and (18\%) had full knowledge about this aspect. Regarding the level of knowledge of vaccination schedule the majority of respondents $(57 \%)$ were found to have partial knowledge followed by 23 per cent had no knowledge and 20 per cent full knowledge.. Regarding the control of foot and mouth disease, the majority of respondents 
(52\%) was found to have partial knowledge followed by had full $(41 \%)$ and no knowledge $(07 \%)$ of this practice, respectively. Regarding control of hemorrhagic septicemia disease the study showed that the majority of (59\%) respondents were found to have partial knowledge followed by and who had full $(27 \%)$ and no knowledge $(14 \%)$ of this practice, respectively. Regarding the control of black quarter disease the majority of $(56 \%)$ respondents was found to have partial knowledge followed by (28\%) and (16\%) who had full and no knowledge of this practice respectively. Regarding the level of knowledge of control of anthrax disease, the study showed that the majority of $(61 \%)$ respondents was found to have partial knowledge followed by 23 and $16 \%$ who had no and full knowledge of this practice, respectively. It was found that majority of the respondents had partial knowledge, about vaccination programme to control the diseases vaccination schedule, control of foot and mouth diseases control of hemorrhagic septicemia diseases, control of black quarter diseases and control of anthrax diseases. These finding were accordance with findings of Kumar et al. (2011).

\section{Knowledge Level about general} management: Management of livestock involves, in doing a large number of small jobs at proper time and in a proper manner. A successful dairy farmers should strive to improve and attain perfection in due course of time with improve knowledge of these practices. The data in table 1depicted the knowledge of respondent about general management practices of herd. It was found that the majority of $(66 \%)$ respondents had partial knowledge of keeping the records of animals followed by no (20\%) and full (14\%) knowledge, respectively. Regarding the method of determining the age of animals, it was found that the majority of (54\%) respondents had partial knowledge followed by no $(26 \%)$ and full (22 \%) knowledge. Regarding the level of knowledge of proper method of milking, the majority of $(56 \%)$ respondents had partial knowledge followed by 28 and $16 \%$ who had full and no knowledge, respectively. It was found that majority of the respondents had partial knowledge about keeping the records of animals, method of determining the age of animals and proper method of milking. These finding are in line with the findings of Aulakh et al. (2011), Kumar et al. (2011) and Rupesh kumar et al. (2011).

\section{Overall Level of knowledge of dairy farmers about dairy practices:-The} government and dairy development agencies has given prior priority for development of dairy in rural areas with efficient use of improved dairy practices to get maximum profit from this enterprise. In this reference, it is a desired to extent the knowledge improved dairy practices possessed by dairy farmers in rural area. The data in table 2 shows that the majority of the farmers $(73 \%)$ had partial level of knowledge about overall dairy practices, while farmers $(16 \%)$ had full level of knowledge about overall dairy practices, and who had no level of knowledge (11\%) about overall dairy practices. The results of the study were similar to the findings reported by Satyanarayan and Jagadeswary, (2010); Kumar et al. (2011); Kumawat et al. (2012) 
and Lohakare et al. (2013) who reported their findings from various parts of India.

Table 2. Respondent's level of knowledge about overall improved dairy practices

\begin{tabular}{|c|c|c|c|}
\hline $\begin{array}{l}\text { S. } \\
\text { N. }\end{array}$ & $\begin{array}{c}\text { Dairy } \\
\text { Practices }\end{array}$ & Frequency & Percentage \\
\hline 1. & $\begin{array}{l}\text { No } \\
\text { Knowledge }\end{array}$ & 11 & 11.00 \\
\hline 2. & $\begin{array}{l}\text { Partial } \\
\text { Knowledge }\end{array}$ & 73 & 73.00 \\
\hline 3. & $\begin{array}{l}\text { Full } \\
\text { Knowledge }\end{array}$ & 16 & 16.00 \\
\hline
\end{tabular}

\section{Conclusion}

It can be concluded that majority of the respondent were found in partial level of knowledge regarding improved dairy practices followed by full knowledge and no knowledge respectively. Regarding the overall knowledge of improved dairy practices, it was found that majority of the respondent had partial knowledge about feed practices, breeding practices, disease control practices and general management practices.

\section{References}

Aulakh GS, Yadav JS \& Singh R. 2011. Knowledge level of dairy farmers regarding recommended buffalo management practices. J. Dairying Foods \& H.S., 30 (2): 147-149.

BAHS. 2019. Basic Animal Husbandry Statistics. 2019. Ministry of Fisheries Animal Husbandry and Dairying, Department of Animal Husbandry and Dairying, Krishi Bhawan, New Delhi.

Kumar S, Kumar B, Hindustani S \& Sankhala G. 2011. Knowledge level of dairy farmers in operational area of krishi vigyan kendra about improved dairy farming practices. Research Journal of Agricultural Sciences, 2 (1): 122-124.

Kumawat R, Yadav JP \& Yadav VPS. 2012. Development of a standardized knowledge test $f$ or measuring knowledge level of dairy farmers about improved dairy husbandry practices. Journal of Community Mobilization and Sustainable Development, 7 (2): 183188.

Lohakare AC, Gawande SH, Khandait VN \& Basunathe VK. 2013. Socio-economic, psychological characteristics of the cattle owners and their relationship with adoption of animal husbandry practices in vidarbha region of Maharashtra. Research Journal of Agricultural Sciences, 4 (3): 359-362.

Meena BS, Singh AK, Chauhan J \& Sankhala G. 2009. Farmers' knowledge on feeding practices of dairy animals in Jhansi District. Indian Res. J. Ext. Edu., 9 (1): 28-31.

Meena MS \& Chauhan JPS. 1999. Awareness of improved dairy farming practices by farmers of Sawai Madhopur District. J. Dairying, Foods \& Home Sci., 18 (1): 58-60.

Rupeshkumar Raval J \& Chandawat MS. 2011. Extent of knowledge of improved animal husbandry practices and socioeconomical characteristics of dairy farmers of district Kheda, Gujarat. 1 (2):129-137.

Satyanarayan K \& JagadeeswaryV. 2010. A study on knowledge and adoption behaviour of livesto ck farmers. Indian J. Anim. Res., 44 (2): 100- 106. 